\title{
EVALUASI PELATIHAN PENYULUH AGAMA ISLAM NON PNS: IMPLEMENTASI, HAMBATAN DAN DAMPAKNYA TERHADAP KOMPETENSI ALUMNI
}

\author{
Agustina \\ Balai Diklat Keagamaan Palembang, Kementerian Agama, Palembang \\ agustinadjihadi.ad@gmail.com
}

\begin{abstract}
Abstrak
Penyuluh Agama adalah corong pemerintah dalam menyampaikan pesan-pesan agama, namun saat ini seringkali dipandang belum menyesuaikan kompetensinya dengan perubahan zaman sehingga perlu mengikuti pelatihan. Penelitian ini bertujuan untuk mengetahui kesesuaian tujuan pelatihan dan kebutuhan penyuluh, input, implementasi dan dampak pelatihan terhadap peningkatan kompetensi penyuluh. Penelitian ini melibatkan 1209 (seribu dua ratus sembilan) alumni pelatihan Penyuluh Agama Islam non PNS dari 28 propinsi sebagai responden survey daring, dan 32 alumni pelatihan dari 6 kabupaten di dua propinsi yaitu Sumatera Selatan dan Lampung sebagai responden wawancara sehingga total responden 1241 (seribu dua ratus empat puluh satu) orang. Data dikumpulkan melalui tiga teknik yaitu mendistribusikan angket daring, melakukan in depth interview untuk mengelaborasi hasil angket sebagai teknik triangulasi metode, dan telaah dokumentasi, lalu dianalisis menggunakan metode deskriptif kualitatif. Hasil penelitian menunjukkan bahwa terdapat relevansi tujuan pelatihan dan kebutuhan Penyuluh Agama Islam Non PNS; aspek kurikulum dan silabus pelatihan perlu mendapat perhatian untuk perbaikan kualitas kedepan; aspek pengelolaan kelas dan penggunaan strategi widyaiswara perlu lebih baik; dan analisis dampak menunjukkan bahwa mayoritas peserta pelatihan telah memiliki peningkatan kompetensi ilmu agama dan Kompetensi Komunikasi sangat baik, dan peningkatan Kompetensi Sosial dan kompetensi moral cukup baik, namun masih kurang baik dalam aspek keterampilan menjalankan fungsi advokatif.
\end{abstract}

Key Words: Evaluasi, Pelatihan, Penyuluh Agama Islam Non PNS 


\begin{abstract}
[EVALUATION ON TRAINING FOR ASSISTED ISLAMIC COUNSELORS: IMPLEMENTATION, OBSTACLES AND IMPACTS ON ALUMNI'S COMPETENCY]. Islamic Counselors are the mouthpieces of the government in conveying religious messages, but they are often seen lack of competence in carrying out the duty so they need to take part in training. This study aims to determine the suitability of training objectives and the Counselors' needs, input, implementation and impact of training on enhancing the counselors' competence in carrying out their duty. This study involved 1209 alumni of assisted Islamic Counselors from 28 provinces in Indonesia as online survey respondents, and 32 training alumni from 6 districts in two provinces, namely South Sumatra and Lampung as interview respondents so that the total respondents were 1241 people. The data were collected through three techniques, namely distributing online questionnaires, conducting in-depth interviews as a method of triangulation, and reviewing documentation, then analyzing using qualitative descriptive method. The results showed that 1) the training objectives were relevant with the needs of assisted Islamic Counselors; and 2) the training curriculum and syllabus, the classroom management and the strategies need to be improved. Besides, the impact analysis noted that the majority of training participants showed better competence in religious and communication competencies, but showed no improvement advocacy skill.
\end{abstract}

Key Word: Evaluation, Training, Assisted Islamic Counselors 


\section{PENDAHULUAN}

Penyuluh Agama merupakan salah satu dari dua jabatan fungsional yang ditetapkan oleh Menteri Pendayagunaan Aparatur Negara untuk dibina oleh Kementerian Agama. Memandang tingkat urgensinya, jabatan Penyuluh Agama telah menjadi sebuah corong pemerintah dalam menyampaikan pesan-pesan agama maupun pesanpesan program pemerintah. Dalam keputusan bersama Menteri Agama RI dan Kepala Badan Kepegawaian Negara Nomor 574 tahun 1999 dan nomor 178 tahun 1999 tentang jabatan fungsional penyuluh agama dan angka kreditnya, keputusan bersama Menteri Agama RI dan Kepala Badan Kepegawaian Negara nomor 574 tahun 1999, disebutkan secara jelas bahwa terdapat fungsi Penyuluh Agama yaitu: fungsi informatif dan edukatif, dimana penyuluh agama memposisikan dirinya sebagai juru dakwah yang berkewajiban mendakwahkan ajaran agamanya, menyampaikan penerangan agama dan mendidik masyarakat dengan sebaik-baiknya sesuai ajaran agama; kedua, fungsi konsultatif, dimana penyuluh agama mengabdikan dirinya untuk turut memikirkan dan memecahkan persoalan-persoalan yang dihadapi masyarakat, baik secara pribadi, keluarga maupun sebagai masyarakat umum; dan ketiga adalah fungsi advokatif, dimana penyuluh agama memiliki tanggungjawab moral dan sosial untuk melakukan pembelaan terhadap umat/masyarakat binaan terhadap berbagai ancaman, gangguan, hambatan, dan tantangan yang merugikan akidah, mengganggu ibadah dan merusak akhlak. Ketiga fungsi ini menunjukkan bahwa jabatan
Penyuluh Agama memegang peran yang sangat penting dalam roda pembangunan dan karenanya layak untuk mendapatkan perhatian yang baik.

Namun, dinilai dari baik kompetensi maupun kinerjanya, para penyuluh agama selama ini sering dipandang belum menyesuaikan diri dengan peran yang diemban dan belum menyesuaikan dengan zaman kekinian yang terus berubah, sehingga diperlukan penyesuaian peran penyuluh agama Islam agar dapat lebih memberikan nilai tambah bagi pembangunan bidang keagamaan di Indonesia (Amirulloh, 2016: 40). Dari perubahan peran inilah diharapkan kompetensi mumpuni yang dipersyaratkan akan menjadi target pencapaian setiap penyuluh yang berimbas pada kinerja sesuai kompetensinya.

Untuk meningkatkan wawasan Penyuluh Agama Islam Non PNS dalam memberikan bimbingan dan penyuluhan kepada masyarakat yang baik dan berkesinambungan, pelatihan bagi Penyuluh Agama Islam Non PNS dilakukan dengan sangat masif pada tiap Balai Diklat Keagamaan seIndonesia, dan baik implementasi maupun hasilnya relatif sangat jarang dievaluasi secara global. Evaluasi pelatihan sendiri merupakan bidang yang banyak diminat para peneliti kepelatihanan, namun khusus untuk pelatihan Penyuluh termasuk area yang masih relatif sedikit dilakukan penelitian. Sudjarwo (2008) meneliti evaluasi kinerja penyelenggaraan pendidikan dan pelatihan Kepemimpinan Tingkat IV pada Balai Pelatihan Keagamaan Semarang dengan hasil status kinerja input kurang, status kinerja proses baik, dan 
status kinerja output sedang. Menurutnya kurangnya kinerja dalam aspek input disebabkan oleh rendahnya komitmen terhadap penyediaan faktor sumber pelayanan.

Dari beberapa penelitian evaluasi pelatihan dapat disimpulkan bahwa pelaksanaan pelatihan tidak selalu berbanding lurus dengan meningkatnya kompetensi Penyuluh Agama Islam secara signifikan dikarenakan berbagai kekurangan. Pada tingkat lembaga pelatihan ini pada kenyataannya memang penyelenggaraan pelatihan Penyuluh Agama Islam masih tidak selalu dibarengi dengan sistem evaluasi yang komprehensif dalam rangka menilai efektivitasnya hingga upaya peningkatan kualitas penyelenggaraannyapun dinilai kurang intens. Selama ini, pada tingkat Balai Pelatihan, evaluasi yang diadakan adalah meliputi hanya evaluasi saat pelatihan (bersifat formatif) dan belum mengevaluasi peserta pasca pelatihan (bersifat sumatif), dengan kata lain evaluasi pada kisaran output dan belum outcome. Evaluasi pelatihan yang kurang komprehensif ini bukan tidak mungkin telah menyebabkan penyelenggaraan pelatihan hanya terkesan sebagai kegiatan formalitas, karena tidak memberikan pengaruh yang signifikan tehadap kinerja Penyuluh Agama Islam secara umum.

Maka peneliti memandang penting untuk mengetahui apakah program pelatihan Penyuluh Agama Islam Non PNS yang dilaksanakan pada Balai Diklat Keagamaan telah mencapai tujuan dengan baik, yaitu meningkatkan kompetensi dan keterampilan Penyuluh Agama dalam menjalankan tugas dan fungsinya. Terkhusus pada pelatihan peningkatan kompetensi Penyuluh Agama Islam, menurut Amirulloh (2016: 55), pengikutsertaan para penyuluh agama Islam ini pada pelatihan masih sering dianggap belum memuaskan karena materi yang disampaikan belum sesuai dengan kebutuhan dan realitas kondisi kelayakan penyuluhan di lapangan. $\mathrm{Hal}$ ini tentu saja dapat mempengaruhi hasil pelatihan yang diperoleh oleh para pesertanya.

Belum memuaskannya

kompetensi penyuluh agama dan urgensi untuk mengevaluasi pelatihan Penyuluh Agama Islam pada lembagalembaga pelatihan seperti yang dipaparkan diatas, menjadi latar belakang penulis untuk melakukan penelitian evaluasi program pelatihan peningkatan kompetensi Penyuluh Agama Islam Non PNS yang diselenggarakan oleh Balai Diklat Keagamaan. Adapun masalah pokok yang diangkat dalam penelitian ini dirumuskan dalam pertanyaan berikut,

1) Apakah sudah terdapat kesesuaian tujuan program pelatihan dengan kebutuhan penyuluh Agama Islam Non PNS dalam menjalankan tusinya?

2) Seberapa baik strategi untuk mendukung tujuan-tujuan yang telah ditetapkan, terutama dalam aspek kurikulum dan silabus?

3) Bagaimana proses implementasi program pelatihan Peningkatan Kompetensi Penyuluh Agama Islam di Balai Pelatihan Keagamaan se-Indonesia?

4) Apakah terdapat peningkatan kompetensi peningkatan kompetensi Penyuluh Agama Islam di Balai Pelatihan Keagamaan se-Indonesia setelah mengikuti program pelatihan? 
5) Hambatan-hambatan apa yang ditemui oleh Para Penyuluh Agama Islam non PNS saat menjalankan tusinya di lapangan?

Berdasarkan deskripsi dan

rumusan permasalahan tersebut, penelitian ini bertujuan untuk; 1) Mengkaji kesesuaian tujuan program pelatihan dengan analisis kebutuhan pelatihan Peningkatan Kompetensi Penyuluh Agama Islam di Balai Pelatihan Keagamaan se- Indonesia, 2) Menidentifikasi strategi untuk mendukung tujuan-tujuan yang telah ditetapkan terutama dalam hal kursil, 3) Mengkaji proses implementasi program pelatihan Peningkatan Kompetensi Penyuluh Agama Islam di Balai Pelatihan Keagamaan seIndonesia, 4) Menganalisis hasil peningkataan kompetensi Peningkatan Kompetensi Penyuluh Agama Islam di Balai Pelatihan Keagamaan se-Indonesia setelah mengikuti pelatihan dan 5) Menjabarkan hambatan yang ditemui para Penyuluh saat menjalankan tusinya di lapangan.

Secara praktis, hasil penelitian ini diharapkan memberi manfaatterhadap; Pengambil Kebijakan, untuk dijadikan sebagai masukan dalam merumuskan berbagai kebijakan sebagai upaya meningkatkan kapasitas sumber daya pendukung implementasi pelatihan penyuluh agama; Pengembang Kurikulum, untuk dijadikan sebagai dasar pijakan untuk pengembangan dan penyempurnaan implementasi pelatihan Penyuluh Agama Islam; dan Instruktur/narasumber pelatihan, untuk dapat digunakan sebagai acuan dalam membuat desain rencana pembelajaran pelatihan penyuluh agama, mengembangkan materi, menggunakan metode pembelajaran yang tepat, dan menggunakan media yang sesuai dengan tema pembelajaran dan kondisi peserta pelatihan.

\section{Hakikat Pelatihan}

Terdapat perbedaan yang mendasar antara istilah pendidikan dan pelatihan. Masadeh (2012: 64) menjelaskan bahwa pelatihan dilengkapi dengan pengalamanpengalaman praktis, sedangkan pendidikan biasanya memiliki pendekatan yang lebih umum, bertujuan untuk mengembangkan pengetahuan, keterampilan dan nilainilai moral dan pemahaman keseluruhan aspek dalam kehidupan dan tidak terbatas pada bidang tertentu. Jika berorientasi pada fokus, menurut Hadipoerwono (1999: 76), pendidikan difokuskan sebagai suatu pembinaan dalam proses perkembangan manusia, dimana manusia itu berpikir sendiri dan mendorong berkembangnya kemampuan dasar yang ada padanya. Sedangkan pelatihan adalah pembinaan kecakapan, kemahiran, ketangkasan (skill building) dalam pelaksanaan tugas. Bisa disimpulkan bahwa pendidikan berorientasi pada teori, dilakukan di dalam kelas, berlangsung lama dan biasanya menjawab "Why", sedangkan pelatihan berorientasi pada praktek, dilakukan di lapangan berlangsung singkat dan menjawab "How".

Goldstein dan Ford (2002:1) menyatakan bahwa "training is defined as the systematic acquisition of skills, rules, concept, or attitudes that result in improved performance in another environment". Ini berarti pelatihan menjadi proses penerimaan 
keterampilan, aturan, konsep dan sikap-sikap tertentu secara sistematis yang menyebabkan terjadinya peningkatan kinerja dalam lingkungan kerjanya. Senada dengan ini, Kamil (2010: 4) mendefinisikan pelatihan sebagai serangkaian aktifitas yang dilaksanakan untuk meningkatkan keterampilan, pengetahuan, pengalaman, keahlian ataupun perubahan sikap dari individu dalam jangka waktu yang relatif singkat dan lebih mengutamakan praktik daripada teori. Namun, penggunaan kata pendidikan dan pelatihan ini seringkali berdampingan, disingkat menjadi Pelatihan.

Dari defenisi-defenisi diatas tentang pelatihan, dapat disimpulkan bahwa pelatihan merupakan sebuah program untuk meningkatkan kompetensi objek yang dipelatihan, dimana dalam penelitian ini merupakan para Penyuluh Agama Islam Non PNS.

\section{Kompetensi Penyuluh Agama}

Penyuluh Agama, sebagaimana tercantum dalam Keputusan Menteri Agama RI nomor 79 Tahun 1985 dan Keputusan Menteri Agama RI Nomor 164 Tahun 1996 (Kemenag: 8), adalah pembimbing umat beragama dalam rangka pembinaan mental, moral dan ketaqwaan kepada Tuhan Yang Maha Esa. Disebutkan bahwa Penyuluh Agama Islam adalah pembimbing umat dalam rangka pembinaan mental, moral, dan ketaqwaan kepada Tuhan dan memberikan pengertian dan penjabaran tentang segala aspek pembangunan melalui bahasa agama.

Sedangkan kompetensi secara bahasa diartikan dalam Kamus Besar Bahasa Indonesia (KBBI: 2017) versi daring sebagai wewenang atau kekuasaan untuk menentukan atau memutuskan suatu hal. Defenisi kompetensi lain oleh Spencer and Spencer (1993: 9) menyebutkan, " $A$ competency is an underlying characteristic of an individual that is causally related to criterion-referenced effective and/or superior performance in $a$ job or situation". Kompetensi dinyatakannya sebagai suatu karakeristik yang mendasar dari seseorang individu, yaitu penyebab yang terkait dengan acuan kriteria tentang kinerja yang efektif. Rusman (2010: 23) mendefinisikan kompetensi merupakan perilaku rasional untuk mencapai tujuan yang dipersyaratkan sesuai dengan kondisi yang dipersyaratkan. Disimpulkan dari defenisi-defenisi diatas, kompetensi dapat dipahami sebagai kecakapan atau kemampuan.

Menurut Keputusan Bersama Menteri Agama dan Kepala Badan Kepegawaian Negara Nomor 574 Tahun 1999 dan Nomor 178 Tahun 1999, disebutkan bahwa kompetensi Penyuluh Agama meliputi; 1) Bimbingan atau penyuluhan agama dan pembangunan: melaksanakan bimbingan penyuluhan, melaksanakan konsultasi, menyusun rencana penyuluhan, menganalisis potensi wilayah, menyusun materi penyuluhan, menyusun laporan penyuluhan, 2) Pengembangan bimbingan atau penyuluhan agama dan pembangunan: menyusun juklak (petunjuk pelaksanaan) dan juknis (petunjuk teknis), mengembangkan metode bimbingan dan penyuluhan, menyusun konsep kepenyuluhan dan mengembangkan materi bimbingan dan penyuluhan, 3) Pengembangan profesi: membuat karya tulis ilmiah dan membimbing penyuluh yang 
adadibawahnya, dan 4) Penunjang tugas: mengikuti seminar atau yang setara, aktif dalam organisasi dan mengikuti pendidikan yang tidak sesuai dengan bidang tugasnya.

Dalam Keputusan Dirjen Bimbingan Masyarakat Islam No 298 tahun 2017 tentang Pedoman Penyuluh Agama Islam Non PNS halaman 13-14 disebutkan bahwa Penyuluh Agama Islam Non PNS berkordinasi dengan Penyuluh Agama Islam Fungsional untuk melakukan penyuluhan agama Islam dalam bidang keislaman dan pembangunan sosial keagamaan, baik di lingkungan Kemenag maupun lembaga mitra lintas sektoral, dengan spesialisasi sebagai berikut; 1) Penyuluh Pemberantasan Buta Huruf Alquran, yang bertugas untuk bertahap menjadikan kelompok binaan dapat membaca dan menulis huruf Alquran, 2) Penyuluh Keluarga Sakinah, yang berperan untuk membentuk keluarga sakinah pada masyarakat, 3) Penyuluh Zakat, yang bertugas untuk meningkatkan pendayagunaan zakat dari dan untuk masyarakat, 4) Penyuluh Wakaf, yang bertugas untuk meningkatkan potensi dan pendayagunaan wakaf dari dan untuk masyarakat, 5) Penyuluh Produk Halal, yang bertugas menciptakan masyarakat muslim Indonesia yang sadar halal, 6) Penyuluh Kerukunan Umat Beragama, yang bertugas mendorong masyarakat untuk menciptakan kerukunan dalam kehidupan beragama, 7) Penyuluh Radikalisme dan Aliran Sempalan, yang bertugas untuk membantu instansi berwenang dalam pencegahan tumbuhnya perilaku radikal dan aliran sempalan di masyarakat dengan pendekatan agama, 8) Perilaku NAPZA dan HIV/AIDS, yang bertugas untuk membantu instansi berwenang dalam proses rehabilitasi pengguna NAPZA dan ODHA dengan pendekatan spiritual.

\section{METODE PENELITIAN}

Penelitian ini menggunakan mixed method (dengan data kuantitatif dan kualitatif) dengan desain studi kasus melalui Model Evaluasi CIPP (context, input, process, dan product) yang dikembangkan oleh Stufflebeam dkk. Penggunaan model CIPP dalam penelitian evaluatif ini bertujuan untuk menghasilkan temuan yang menyeluruh dan komprehensif terhadap seluruh aspek dalam implementasi program pelatihan karena model evaluasi ini digambarkan lebih komprehensif jika dibandingkan dengan model evaluasi lainnya Madaus, et al (2001) dan merupakan model evaluasi holistik yang elemen-elemennya beroreantasi sistem serta terstruktur dalam mengakomodasi kebutuhan evaluasi universal.

Penelitian ini dilakukan dengan prosedur daring dan tatap muka. Penelitian daring melibatkan 1209 (seribu dua ratus sembilan) orang Penyuluh Agama Non PNS yang pernah mengikuti pelatihan pada 13 Balai Pelatihan Keagamaan yang tersebar di Indonesia yang berasal dari total 28 propinsi. 


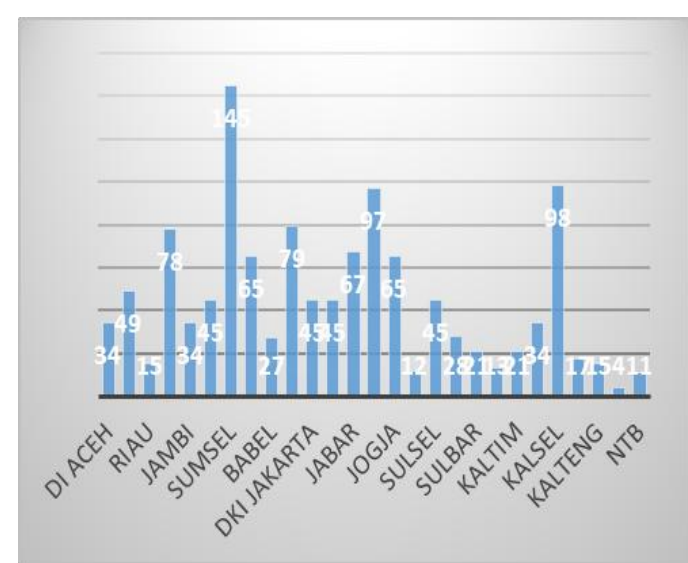

Grafik 1. Responden Penelitian Daring

Peneliti juga melakukan visitasi ke lapangan dengan melibatkan 32 (tiga puluh dua) responden Penyuluh Agama Non PNS yang berasal dari 5 (lima) kota/kabupaten di propinsi Sumatera Selatan dan Lampung.

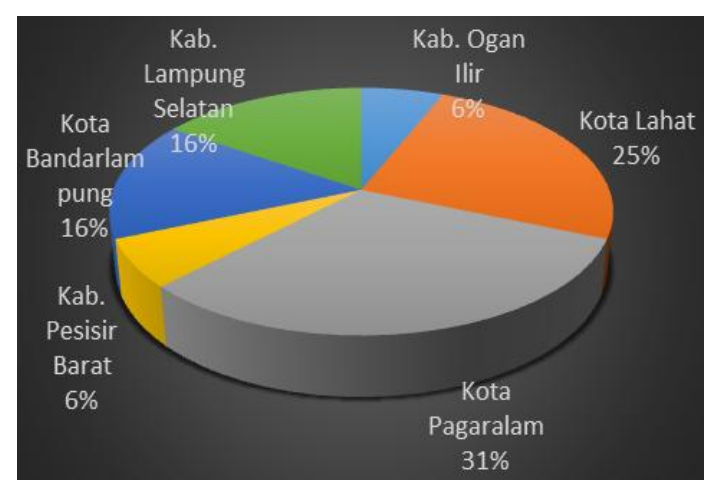

Grafik 2. Responden Wawancara

Pengambilan data dilakukan dalam kurun waktu 13 Agustus hingga 17 September 2020, analisis data hingga penulisan hasil penelitian dilakukan pada Oktober-Desember $2020 . \quad$ Data dikumpulkan melalui tiga teknik berikut.

1) Penyebaran Kuesioner Online. Kuisioner didistribusikan secara online kepada para Penyuluh Agama Islam non PNS se-Indonesia. Adapun jenis kuesioner yang digunakan adalah kuesioner online dengan pertanyaan tertutup sebanyak 19 (sembilan belas) butir pertanyaan dengan opsi respon dengan Skala Likert. Validitas masingmasing instrument dalam penelitian ini telah dianalisis dengan metode uji analisis validitas isi. Peneliti menyusun sebuah Tabel Spesifikasi berdasarkan indikator-indikator pelaksanaan pelatihan untuk dimasukkan dalam format kuisioner dan menyesuaikan butir-butir pernyataannya dengan kusioner tersebut. Dalam memvalidasi konten, penulis juga meminta pendapat ahli (expert judgment) berdasarkan spesifikasi yang telah disusun sebelumya.

2) Wawancara Mendalam (In-depth Interview.)

Wawancara dalam penelitian ini dilakukan secara individual pada satuan kerja KUA responden yang tersebar dalam 6 kecamatan di propinsi Sumsel dan Lanmpung, secara spesifik bertujuan untuk mengelaborasi atau memperkaya infiormasi yang telah diperoleh. Adapun jenis wawancara yang dilakukan peneliti adalah wawancara terstruktur. Bersama dengan hasil angket dan analisis dokumentasi, hasil wawancara menjelaskan secara deskriptif tentang aspek-aspek penelitian secara elaboratif.

\section{3) Telaah Dokumentasi}

Penulis menggunakan metode dokumentasi untuk evaluasi salah satu sub indikator dalam evaluasi konteks yaitu menganalisis tujuan program pelatihan Penyuluh Agama Islam Non PNS dan evaluasi input yaitu kurikulum dan silabus pelatihan Penyuluh Agama Islam Non PNS sebagai salah satu teknik triangulasi bersamaan dengan teknik wawancara dan penyebaran angket.

Adapun prosedur analisis data mengacu pada prosedur analisis data Miles \& Hubermen (1994), yaitu bahwa analisis data dalam penelitian kualitatif, secara umum dimulai sejak pengumpulan data, reduksi data, penyajian data, dan penarikan kesimpulan atau verifikasi. Dalam menganalisis data, peneliti melakukan teknik berikut:

1) Analisis angket daring secara kuantitatif: skoring, mentabulasi, melakukan interpretasi. 
2) Analisis hasil wawancara dengan menggunakan persentase untuk mengelaborasi hasil yang diperoleh sebelumnya dari angket daring.

3) Analisis dokumentasi yaitu dengan membandingkan teks naskah kursil Pelatihan yang memuat tujuan pelatihan dan mengkaitkannya dengan kebutuhan alumni yang ditanyakan via wawancara.

\section{TEMUAN DAN PEMBAHASAN}

1. Temuan

a. Aspek Relevansi Kebutuhan dan Tujuan Program Pelatihan Penyuluh Agama Islam Non PNS dalam Menjalankan Tusinya

Para Penyuluh Agama Islam Non PNS menilai pelatihan yang mereka ikuti telah memiliki relevansi yang sangat baik dengan kebutuhan mereka di lapangan, ditunjukkan baik oleh hasil angket maupun wawancara. Adapun telaah dokumen mencatat mengkonfirmasi kesesuaian antara tujuan pelatihan dan kebutuhan dan tusi penyuluh Agama Islam di lapangan. Dari ketiga hasil yang sama yang diperoleh dengan tiga teknik pengumpulan data yang berbeda disimpulkan bahwa terdapat relevansi yang kuat antara kebutuhan Penyuluh Agama Islam non PNS dalam menjalankan tusinya dengan tujuan pelatihan Penyuluh Agama Islam Non PNS.

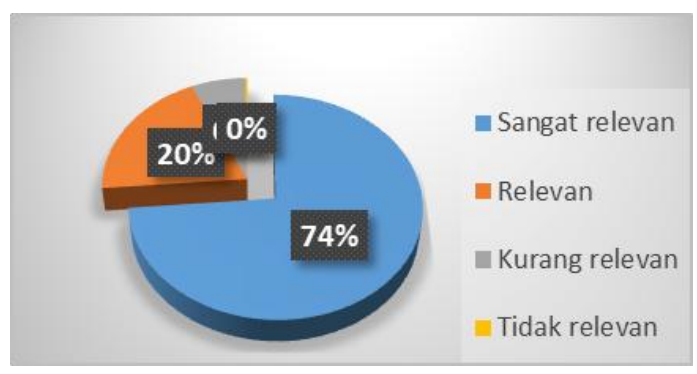

Grafik 3. Relevansi Tujuan Pelatihan dengan Kebutuhan Penyuluh di Lapangan
1) Input/Masukan Kursil Pelatihan Teknis Substantif Penyuluh Agama Islam Non PNS

Mayoritas responden sudah menilai positif aspek kursil, meski terdapat angka yang cukup besar yang menyatakan ketidakpuasannya terhadap kursil yang ada.

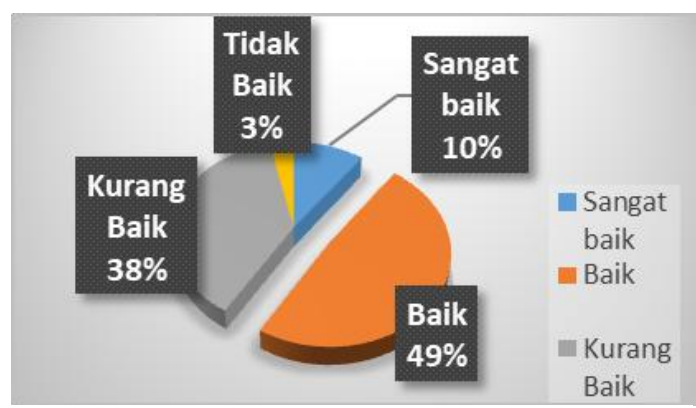

Grafik 4. Kurikulum dan Silabus

Untuk butir pernyataan tentang kursil, ada sub pertanyaan yang meminta masukan responden materi yang perlu dimasukkan dan selama ini belum terakomodir dalam kursil Pelatihan Penyuluh Agama Non PNS. 


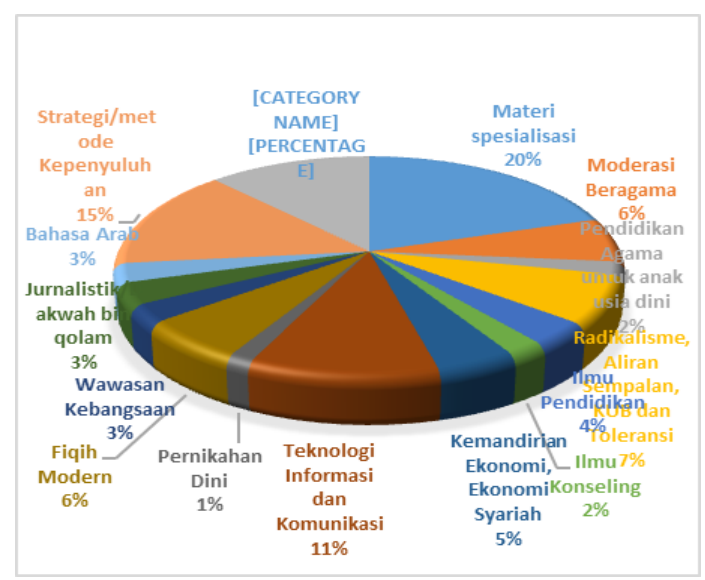

Grafik 5. Masukan Materi untuk Kursil

Responden menghendaki adanya beragam isu untuk dimasukkan kedalam kursil, dimana saat wawancara juga terdapat banyak pendapat menyebutkan bahwa muatan pelatihan masih sangat umum dan diharapkan untuk dapat lebih menukik pada spesialisasi dengan porsi yang lebih banyak. Hal ini diungkapkan salah satunya oleh salah satu penyuluh agama di Kota Lahat, "Kami membutuhkan penguatan pada bidang spesialisasi kami yang sumber belajar mandirinya masih sangat kurang, misalnya pada bidang Narkoba. Wawasan yang kami peroleh dari pelatihan masing bersifat sangat umum, hingga kami masih kesulitan dalam menjalankan tugas dalam spesialisasi tersebut".

2) Analisis Implementasi Strategi Pelatihan Teknis Subtantif Penyuluh Agama Islam Non PNS

Strategi dan metode pembelajaran yang diterapkan dalam pelatihan merupakan sebuah aspek yang cukup banyak mendapat perhatian responden. Terdapat persentase yang cukup besar yang merasakan ketidakpuasan dalam hal strategi dan metode pembelajaran yang diterapkan widyaiswara, yaitu total sebesar $43 \%$. Ini berarti hampir separuh responden berpendapat bahwa aspek strategi dan metode pembelajaran perlu ditingkatkan lebih baik.

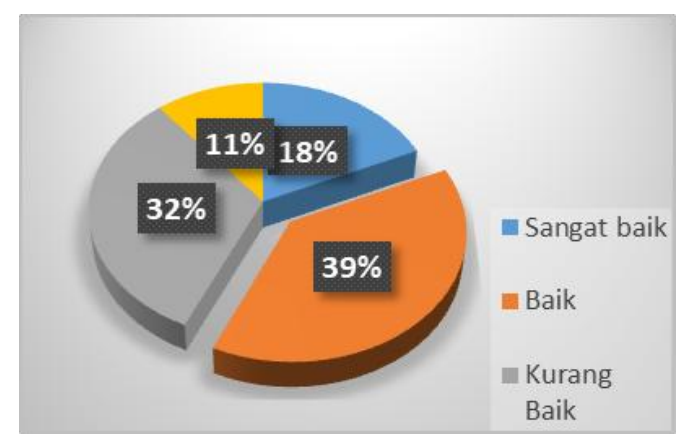

Grafik 6. Implementasi Strategi Pelatihan

Dalam aspek ini, terdapat sub pertanyaan yang meminta responden memberikan masukan aspek mana dari strategi dan metode pembelajaran yang diterapkan widyaiswara yang perlu diperbaiki.

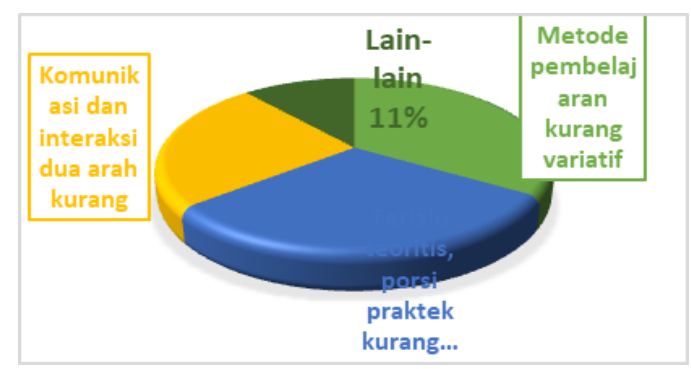

Grafik 6. Aspek Strategi yang Perlu Diperbaiki

Terdapat 408 responden menyebutkan bahwa metode pembelajaran masih kurang variatif dan cenderung monoton, sebagian lagi menyebutkan bahwa pembelajaran berlangsung terlalu serius, sebanyak 367 responden menyebut bahwa widyaiswara terlalu banyak memberikan teori, sedangkan peserta membutuhkan praktek dan problemsolving yang kontekstual, sebanyak 298 responden menyebutkan bahwa kurang interaksi dua arah antara WI dan peserta, peserta kurang dilibatkan, sementara peserta menghendaki keterlibatan yang lebih aktif dalam pembelajaran karena komunikasi satu arah cenderung membuat peserta lebih cepat mengantuk. Hal yang sama dikemukakan oleh responden saat wawancara berlangsung, salah satunya oleh salah satu penyuluh pada salah satu KUA di Pagaralam, "Widyaiswara diharapkan dapat 
mengaktifkan peserta untuk lebih banyak terlibat dalam pembelajaran, hingga kami benar-benar maksimal dalam memahami apa yang disampaikan".

\section{3) Peningkatan Kompetensi Penyuluh Agama Islam Non PNS}

Aspek peningkatan kompetensi penyuluh ditanyakan dalam angket daring dikarenakan jawaban yang diperoleh secara daring diharapkan telah cukup representatif dan lebih tinggi objektivitasnya dibandingkan jawaban self-evaluation melalui wawancara. Responden biasanya akan merasa sungkan untuk menilai diri sendiri secara langsung jika dibandingkan dengan melakukan self-evaluation secara tertutup melalui angket daring.

a) Kompetensi Ilmu Agama

Mayoritas responden merasakan mendapatkan peningkatan kompetensi agama yang signifikan pasca mengikuti pelatihan Penyuluh Agama Non PNS. Hal ini mengindikasikan bahwa muatan materi agama dalam Pelatihan Penyuluh Agama Non PNS sudah sangat memadai.

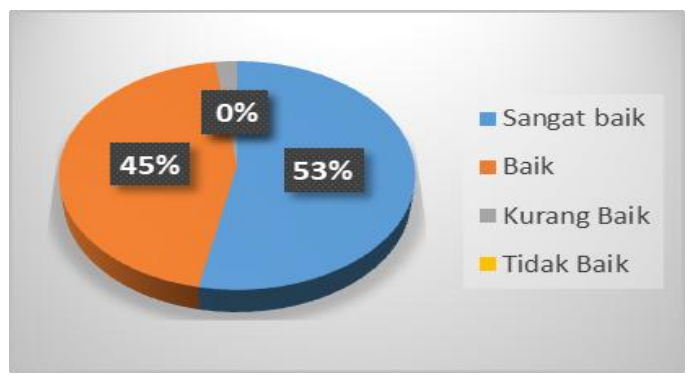

Grafik 7. Kompetensi Ilmu Agama

b) Kompetensi Komunikasi

Kompetensi komunikasi adalah kemampuan berkomunikasi yang baik meliputi mampu menyampaikan ceramah agama atau khotbah serta kedua, mampu berkomunikasi yang baik dalam menyampaikan konsultasi agama. Dari hasil angket diperoleh data bahwa sebanyak 59\% responden menilai dirinya mengalami peningkatan kompetensi komunikasi sangat baik pasca diklat.

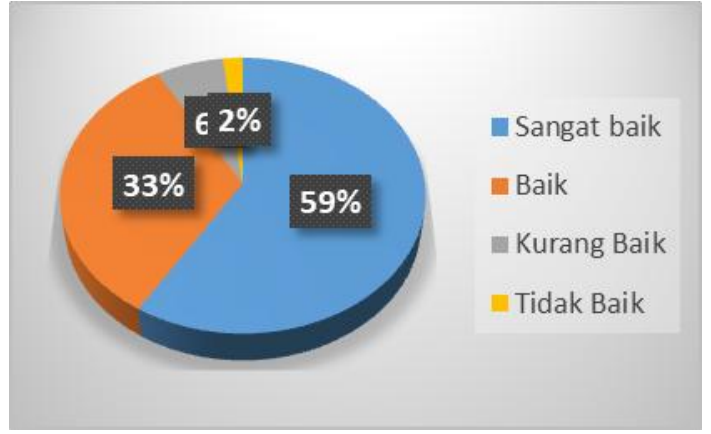

Grafik 8. Kompetensi Komunikasi

c) Kompetensi Sosial

Kompetensi sosial adalah kecakapan dalam bermasyarakat, di antaranya aktif di dalam organsiasi keagamaan atau kemasyarakatan. Hasil angket menunjukkan bahwa sebanyak total $74 \%$ responden merasa terdapat peningkatan kompetensi sosial pasca diklat secara signifikan, namun sebanyak total $26 \%$ responden menilai peningkatan dalam kompetensi sosialnya kurang dan tidak baik.

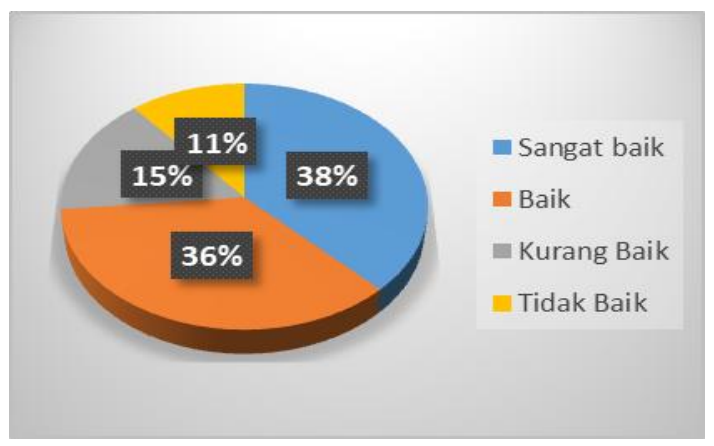

Grafik 9. Kompetensi Sosial

\section{d) Kompetensi Moral}

Kompetensi moral meliputi berakhlak baik dan tidak sedang terlibat dalam masalah hukum. Berdasarkan hasil angket, diperoleh data bahwa hanya sebanyak $27 \%$ responden menilai peningkatan kompetensi moralnya pascadiklat sangat baik, sebanyak $43 \%$ responden mengalami peningkatan yang cukup baik, sedangkan total 30\% responden menganggap pelatihan tidak memiliki dampak signifikan langsung terhadap kompetensi moral Penyuluh Agama Islam Non PNS. Berikut ini data dalam bentuk grafik. 


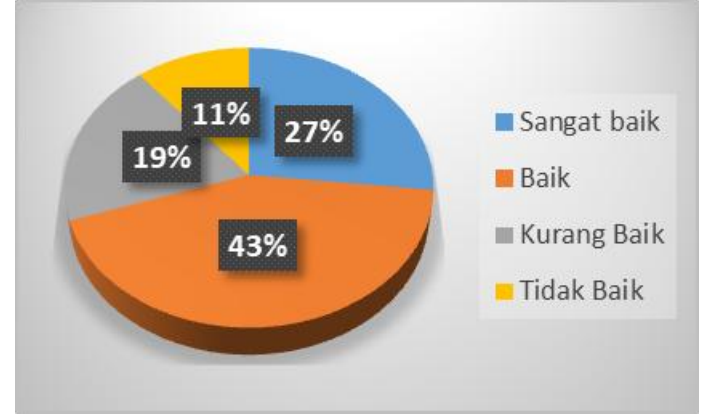

Grafik 10. Kompetensi Moral

4) Peningkatan Keterampilan dalam Menjalankan Fungsi Penyuluh Agama Islam Non PNS

a) Fungsi Informatif

Dari hasil angket diperoleh data bahwa sebanyak 655 responden menilai dirinya mengalami peningakatan keterampilan dalam menjalankan fungsi informatif sangat baik, sebanyak $33 \%$ merasa peningkatan tersebut cukp baik, sedangkan hanya total $13 \%$ responden yang merasa kurang dan tidak baik. Hal ini mengindikasikan bahwa mayoritas responden menilai bahwa terdapat peningkatan yang signifikan pasca diklat dalam menjalankan fungsi informatif.

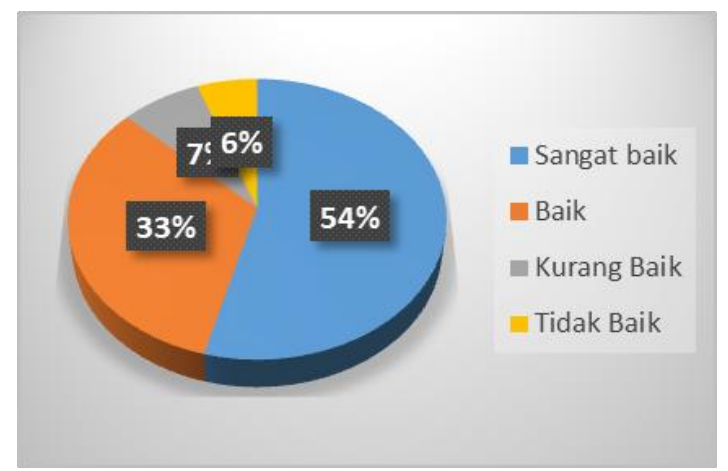

Grafik 11. Fungsi Informatif

\section{b) Fungsi Edukatif}

Dari hasil angket diperoleh data bahwa sebanyak $46 \%$ responden menilai dirinya mengalami peningaktan keterampilan dalam menjalankan fungsi edukatif sangat baik, sebanyak $43 \%$ merasa peningkatan tersebut cukup baik, sedangkan hanya total $11 \%$ responden yang merasa kurang dan tidak baik. Hal ini mengindikasikan bahwa mayoritas responden menilai bahwa terdapat peningkatan yang signifikan pasca diklat dalam menjalankan fungsi edukatif.

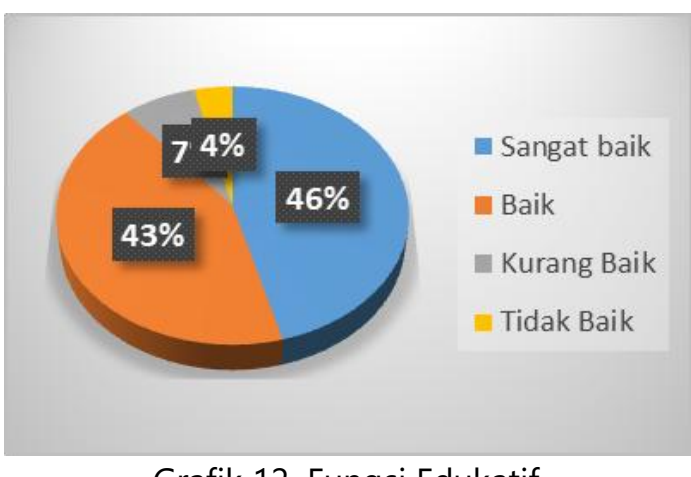

Grafik 12. Fungsi Edukatif

c) Fungsi Konsultatif

Dari hasil angket diperoleh data bahwa sebanyak $38 \%$ responden menilai dirinya mengalami peningkatan keterampilan dalam menjalankan fungsi konsultatif sangat baik, sebanyak $43 \%$ merasa peningkatan tersebut cukup baik, sedangkan hanya $10 \%$ responden yang merasa kurang baik dan 9\% responden merasa tidak baik. Hal ini mengindikasikan bahwa mayoritas responden menilai bahwa terdapat peningkatan yang signifikan pasca diklat dalam menjalankan fungsi konsultatif.

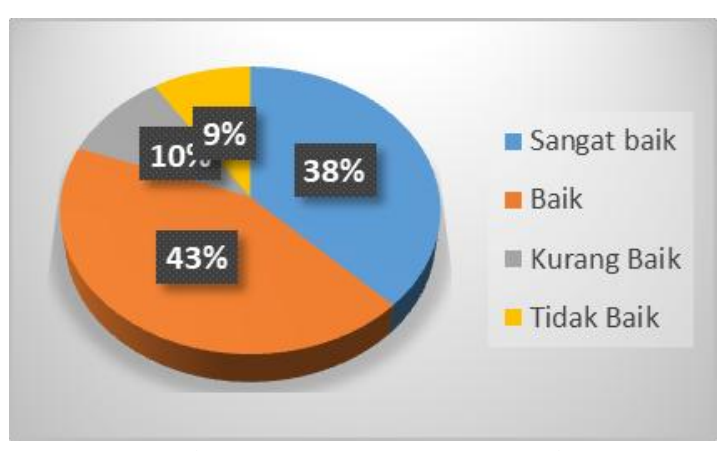

Grafik 13. Fungsi Konsultatif

d) Fungsi Advokatif

Dari hasil angket diperoleh data bahwa sebanyak $27 \%$ responden menilai dirinya mengalami peningkatan keterampilan dalam menjalankan fungsi konsultatif sangat baik, sebanyak 30\% merasa peningkatan tersebut cukup baik, sebanyak 33\% responden merasa kurang baik dan $10 \%$ responden merasa tidak baik. Berbeda dari ketiga fungsi diatas, fungsi advokatif dianggap sebagian responden 
tidak banyak mengalami peningkatan pasca diklat. Hal ini diindikasikan oleh total $43 \%$ responden merasa tidak mengalami peningakatan dalam menjalankan fungsi advokatif.

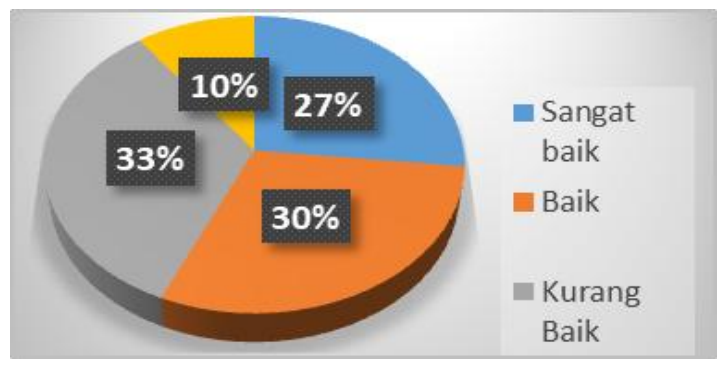

Grafik 14. Fungsi Advokatif

5) Hambatan yang dialami Penyuluh dalam Mengaplikasikan IImu dan Mengembangkan Hasil Pelatihan

Terkait dengan hasil pelatihan, peneliti menginvestigasi hambatan apa saja yang dialami oleh para alumni pelatihan dalam mengaplikasikan ilmu dan mengembangkan hasil pelatihan di lapangan. Terdapat beragam jawaban yang variatif yang diperoleh dari responden angket namun dirangkum secara singkat dalam grafik berikut ini.

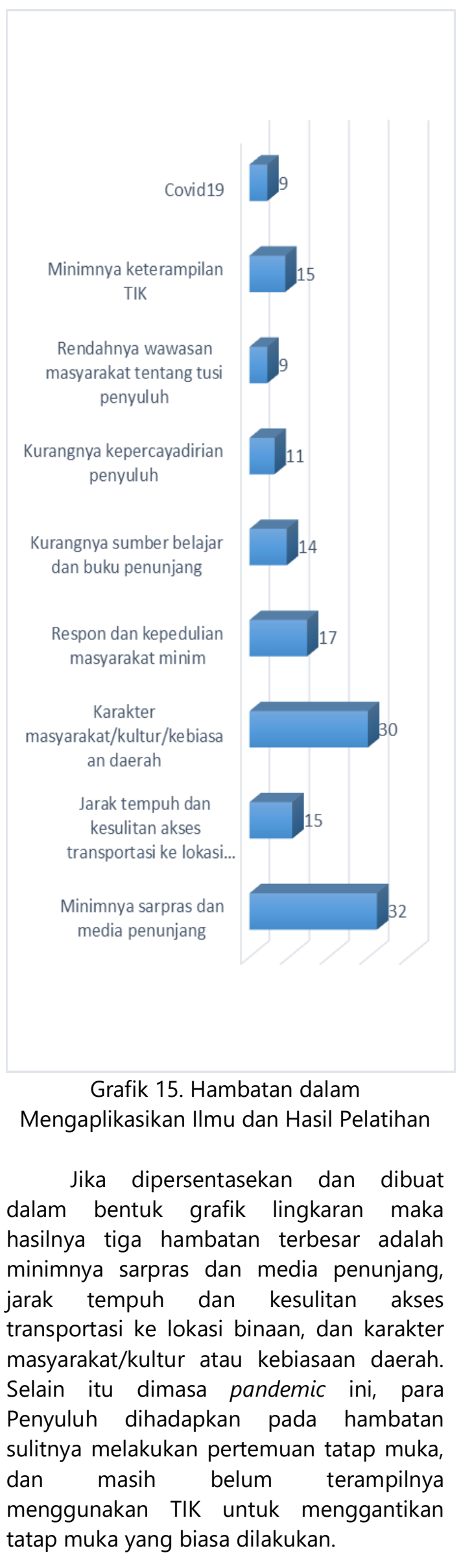


Hal ini menandakan bahwa diperlukannya penguatan keterampilan TIK yang mumpuni untuk para penyuluh agama bisa tetap eksis menjalankan tugasnya di tengah-tengah masyarakat, diperlukannya penguatan penggunaan beragam strategi dalam mengatasi resistensi dan kultur masyarakat yang tidak responsif terhadap dakwah, dan diperlukan dukungan terhadap para penyuluh agama Islam Non PNS dalam aspek pengadaan sarana dan prasarana serta media penunjang, yang dalam hal ini dapat dilakukan oleh Kelompok kerja Penyuluh (Pokjaluh) Kabupaten masingmasing.

\section{Pembahasan}

Pelatihan Penyuluh Agama Islam telah memiliki relevansi tujuan yang baik dengan kebutuhan para Penyuluh Agama dalam menjalankan tusinya di lapangan, seperti yang ditunjukkan oleh hasil evaluasi konteks dalam penelitian ini.

Evaluasi Input, yang mengkaji keadaan objektif meliputi strategi, prosedur dan sumber daya yang dilakukan dalam melaksanakan program demi tercapainya tujuan, dalam hal ini adalah masukan instrumentasi/instrumental input (kurikulum dan silabus pelatihan), menunjukkan hasil, mayoritas responden sudah menilai positif aspek kursil, meski terdapat angka yang cukup besar yang menyatakan ketidakpuasannya terhadap kursil yang ada yaitu sekitar $41 \%$. Terdapat $20 \%$ responden menghendaki kursil memuat materi spesialiasi penyuluh, sebanyak $15 \%$ menghendaki adanya penajaman dalam materi strategi dan metode kepenyuluhan, dan sebanyak 12\% menghendaki adanya materi khusus tentang komunikasi publik/public speaking/retorika dakwah, $11 \%$ menghendaki adanya material tentang teknologi infiormasi dan komunikasi
(TIK), sedangkan sisanya memberikan masukan materi-materi lain. Dapat disimpulkan bahwa responden menghendaki adanya isu-isu lain untuk dimasukkan dalam kurikulum dan silabus pelatihan, dan hal yang sama juga ditunjukkan dari hasil wawancara langsung, dimana sebagian besar dari responden menyebutkan bahwa kursil Pelatihan Penyuluh Agama Islam Non PNS masih terlalu umum, dan tidak banyak menyentuh aspek spesialisasi para penyuluh hingga ilmu yang diperoleh banyak yang tidak "menukik" untuk diterapkan di lapangan.

Urgensi untuk memperbaiki muatan kurikulum dan silabus dalam pelatihan Penyuluh Agama Islam non PNS ini terutama dalam muatan keterampilan berkomunikasi ini relevan dengan apa yang disebut oleh Adrian (2019: 33-34) bahwa kegiatan Penyuluh Agama Islam dalam menjalankan fungsi penyuluhan dapat berjalan dengan baik jika memiliki pola komunikasi yang baik. Disebutkan olehnya bahwa kegiatan penyuluhan dalam konteks disiplin ilmu komunikasi pada hakikatnya adalah proses interaksi hubungan antara penyuluh dengan binaannya yang disebut juga Khazanah Sosial, dengan pola komunikasi. Pola komunikasi yang merupakan sebuah sistem gambaran atau rancangan darikegiatan komunikasi yang berlangsung antara Penyuluh dan binaannya inilah yang perlu diperkuat menurut aspirasi dari para penyuluh agama Islam non PNS yang menjadi responden.

Selanjutnya pada Evaluasi Proses, yang meneliti implementasi program Pelatihan Penyuluh Agama Islam Non PNS untuk mencapai tujuan pelatihan, dalam hal ini adalah implementasi strategi pelatihan oleh widyaiswara, menunjukkan hasil hampir separuh 
responden yaitu sebanyak total $47 \%$ merasa tidak puas dengan pengelolaan kelas oleh WI. Hal ini mengindikasikan bahwa aspek pengelolaan kelas menjadi unsur yang perlu diperbaiki dalam pelatihan Penyuluh Non PNS. Dalam wawancara, para responden menyebut bahwa pengelolaan kelas yang dianggap perlu diperbaiki adalah dalam hal interaksi antar WI, yaitu perlunya pelibatan peserta pelatihan lebih tinggi dalam tiap aktivitas pelatihan, dan kedisiplinan waktu dalam pembelajaran. Terdapat persentase yang cukup besar yang merasakan ketidakpuasan dalam hal strategi dan metode pembelajaran yang diterapkan widyaiswara, yaitu total sebesar $43 \%$. Ini berarti hampir separuh responden berpendapat bahwa aspek strategi dan metode pembelajaran perlu ditingkatkan lebih baik. Aspek dari strategi dan metode pembelajaran yang diterapkan widyaiswara yang perlu diperbaiki adalah metode pembelajaran masih kurang variatif dan cenderung monoton, bahwa widyaiswara terlalu banyak memberikan teori, sedangkan peserta membutuhkan praktek dan problem-solving yang kontekstual, kurang interaksi dua arah antara WI dan peserta, peserta kurang dilibatkan, sementara peserta menghendaki keterlibatan yang lebih aktif dalam pembelajaran.

Terdapat banyak ragam metode dan teknik penyampaian materi dalam pelatihan, namun menurut Clark (2019) tidak ada satu metode penyampaian yang terbaik dibandingkan ragam metode lainnya. Menurutnya, pelatihan akan berjalan dengan baik jika para pelatih menggabungkan beragam metode tersebut dalam pelatihan, tergantung dari kebutuhan dan situasi kontekstual saat itu. yang lebih penting menurutnya adalah, "Learning takes place when the trainees have psychological attachment in the training activities". Hal yang lebih penting adalah memastikan bahwa widyaiswara benar-benar terlibat penuh dan mengaktifkan para peserta dalam tiap aktivitas pelatihan.Selain itu, Ramli dkk (2018) juga menyebutkan bahwa efektifvitas pelatihan dan performa alumninya di tempat tugasnya sangatlah tergantung dari tingkat partisipasi mereka saat mengikuti aktivitas-aktivitas pelatihan.

Selanjutnya adalah Evaluasi Produk, yang meneliti tingkat ketercapaian tujuan Pelatihan dalam hal ini peningkatan kompetensi dan peningkatan berjalannya fungsi para penyuluh agama Islam Non PNS, menunjukkan hasil, mayoritas peserta pelatihan telah memiliki peningkatan kompetensi ilmu agama dan Kompetensi Komunikasi sangat baik, dan peningkatan Kompetensi Sosial dan kompetensi moral cukup baik. Hal ini mengindikasikan bahwa muatan pelatihan yang bersinggungan dengan ilmu agama dan ilmu komunikasi sudah memadai, sedangkan muatan pelatihan yang bersinggungan dengan ilmu sosial dan moral masih perlu ditingkatkan.

Mayoritas responden juga menilai bahwa terdapat peningkatan yang signifikan pasca diklat dalam menjalankan fungsi informatif, fungsi edukatif dan fungsi Konsultatif. Namun berbeda dengan keterampilan menjalankan Fungsi Advokatif yang dianggap sebagian responden tidak banyak mengalami peningkatan pasca diklat. Hal ini diindikasikan oleh total hanya $57 \%$ responden yang merasa mengalami peningkatan keterampilan dalam menjalankan fungsi advokatif, dan $43 \%$ tidak. 
Analisis hambatan yang dialami penyuluh dalam mengaplikasikan ilmu dan mengembangkan hasil pelatihan menunjukkan bahwa hambatan yang paling banyak dialami alumni pelatihan adalah minimnya sarpras dan media pendukung kegiatan kepenyuluhan, karakter masyarakat/kultur masyarakat daerah yang masih konvensional dengan ilmu baru, dan respon/kepedulian masyarakat yang minim. Hal-hal ini sebaiknya menjadi bahan untuk problem-solving dalam pelatihan hingga penyuluh dapat memecahkan berbagai hambatan tersebut dengan baik.

Terkait dengan dampak pelatihan, ditegaskan oleh Sheeba dkk., (2020: 264), bahwa hanya hadir dalam program pelatihan tidak akan membuat alumninya mendapat keuntungan apapun jika mereka tidak mengaplikasikan KSA (Knowledge, Skills, and Abilities, atau Pengetahuan, Keterampilan dan Kemampuan) kedalam tindakan-tindakannya. "Merely attending training programs will not make employees proficient unless or until it (the KSAs) is put into action. Whatever the employees learn (knowledge, skills, and change in behavior) in the trainings it should be applied on the job". Disinilah urgensi komitmen peserta pelatihan untuk membekaskan dampak pelatihan dalam tusinya sebagai Penyuluh menjadi sedemikian besar, jika tidak mau KSA yang telah diterima sepanjang pelatihan menguap begitu saja. Kordinasi yang baik antara penyuluh senior dan Kelompok Kerja Penyuluh menjadi penting sebagai tindak lanjut pelatihan.

$$
\text { Berdasarkan hal-hal tersebut, }
$$
dapat disebutkan bahwa terdapat banyak isu yang perlu diperbaiki yang menjadi tantangan pelatihan kedepan oleh Balai Diklat Keagamaan, yaitu untuk memperbaiki muatan kurikulum dan silabus dalam pelatihan Penyuluh Agama Islam non PNS ini terutama dalam muatan keterampilan berkomunikasi, meningkatkan aspek strategi dan metode pembelajaran oleh widyaiswara, dan meningkatkan efektivitas pelatihan untuk memperoleh dampak kompetensi penyuluh yang lebih baik. Bagi pokjaluh, isu hambatan menjadi penting sebagai referensi untuk membangun lagi kesolidan internalnya dalam mengatasi masalah-masalah yang dialami para penyuluh dl lapangan. Dengan kerjasama yang baik dari berbagai unsur pelatihan, para peserta akan mendapatkan hasil yang maksimal untuk dapat diterapkan di unit kerjanya. Perbaikan dalam isu-isu dalam pelatihan Penyuluh diatas relevan dengan yang disebutkan Elizar dan Tanjung (2018: 47) bahwa pelaksanaan suatu program pelatihan dan pengembangan dapat dikatakan berhasil apabila dalam diri para peserta pelatihan dan pengembangan tersebut terjadi suatu proses tranformasi. Menurutnya proses transformasi tersebut dapat dinyatakan berlangsung dengan baik apabila terjadi paling sedikit dua hal yaitu: peningkatan kemampuan dalam melaksanakan tugas dan perubahan perilaku yang tercermin pada sikap, disiplin, dan etos kerja dari karyawan tersebut.dengan demikian arti penting pelatihan adalah untuk meningkatkan kinerja pegawai dan menghasilkan prestasi yang memuaskan dalam suatu organisasi atau instansi.

\section{PENUTUP}

\section{A. Simpulan}

1. Telah terdapat kesesuaian antara 
tujuan pelatihan dan kebutuhan penyuluh agama seperti yang diindikasikan oleh hasil evaluasi konteks dalam penelitian.

2. Evaluasi Input, yang mengkaji keadaan objektif meliputi strategi, prosedur dan sumber daya yang dilakukan dalam melaksanakan program demi tercapainya tujuan, dalam hal ini adalah masukan instrumentasi/instrumental input (kurikulum dan silabus pelatihan), menunjukkan hasil, mayoritas responden sudah menilai positif aspek kursil, meski terdapat angka yang cukup besar yang menyatakan ketidakpuasannya terhadap kursil yang ada yaitu sekitar $41 \%$.

3. Evaluasi Proses, yang meneliti implementasi program Pelatihan Penyuluh Agama Islam Non PNS untuk mencapai tujuan pelatihan, dalam hal ini adalah implementasi strategi pelatihan oleh widyaiswara, menunjukkan hasil hampir separuh responden merasa tidak puas dengan pengelolaan kelas oleh WI. Hal ini mengindikasikan bahwa aspek pengelolaan kelas menjadi unsur yang perlu diperbaiki dalam pelatihan Penyuluh Non PNS.

4. Evaluasi Produk, yang meneliti tingkat ketercapaian tujuan Pelatihan dalam hal ini peningkatan kompetensi dan peningkatan berjalannya fungsi para penyuluh agama Islam Non PNS, menunjukkan hasil Mayoritas peserta pelatihan telah memiliki peningkatan kompetensi ilmu agama dan Kompetensi Komunikasi sangat baik, dan peningkatan Kompetensi Sosial dan kompetensi moral cukup baik. Mayoritas responden juga menilai bahwa terdapat peningkatan yang signifikan pasca diklat dalam menjalankan fungsi informatif, fungsi edukatif dan fungsi Konsultatif. Namun berbeda dengan keterampilan menjalankan Fungsi Advokatif yang dianggap sebagian responden tidak banyak mengalami peningkatan pasca diklat.

5. Terkait dengan hasil pelatihan, analisis hambatan yang dialami penyuluh dalam mengaplikasikan ilmu dan mengembangkan hasil pelatihan menunjukkan bahwa hambatan yang paling banyak dialami alumni pelatihan adalah minimnya sarpras dan media pendukung kegiatan kepenyuluhan, karakter masyarakat/kultur masyarakat daerah yang masih konvensional dengan ilmu baru, dan respon/kepedulian masyarakat yang minim. Hal-hal ini sebaiknya menjadi bahan untuk problem-solving dalam pelatihan hingga penyuluh dapat memecahkan berbagai hambatan tersebut dengan baik.

\section{B. Rekomendasi}

Tantangan pelatihan kedepan tak pelak membutuhkan kajian yang lebih serius untuk lebih meningkatkan dampak pelatihan yang lebih baik pada para alumninya. Berdasarkan hasil penelitian diatas, peneliti merekomendasikan kepada berbagai pihak untuk dapat menjembatani kondisi penyuluh dalam realita dengan mengambil tantangan pelatihan kedepan yang lebih berkualitas. Rekomendasi dirumuskan sebagai berikut, kepada,

1. Pengembang kursil Pelatihan Penyuluh Agama pada tingkat pusat, untuk dapat memperkaya kurikulum dan silabus dengan muatan yang spesifik menyentuh spesialisasi penyuluh juga isu-isu modern kontekstual yang relevan dengan tantangan kekinian para penyuluh di lapangan, dan lebih meningkatkan muatan pelatihan yang bersinggungan dengan ilmu sosial dan moral, dan muatan pelatihan yang relevan dengan peningkatan keterampilan Penyuluh Agama Islam dalam menjalankan Fungsi Advokat.

2. Pelaksana pelatihan di tingkat Balai Diklat dalam hal ini para Widyaiswara pengampu Pelatihan Penyuluh di tingkat Balai Diklat Keagamaan untuk dapat meningkatkan keterampilan 
pengelolaan kelas terutama dalam aspekinteraksi antar $\mathrm{Wl}$, yaitu perlunya pelibatan peserta pelatihan lebih tinggi dalam tiap aktivitas pelatihan, dan kedisiplinan waktu dalam pembelajaran. Kepada para WI pengampu juga direkomendasikan untuk meningkatkan metode simulasi dan problem-solving dalam pelatihan hingga penyuluh dapat memecahkan berbagai hambatan dalam menjalankan tusi di lapangan secara kontekstual dengan baik.

3. Kelompok Kerja Penyuluh (Pokjaluh) di tingkat Kabupaten/Kota sebagai wadah antar Penyuluh Agama Islam untuk dapat mengaktifkan kordinasi dan komunikasi yang baik dalam bersama-sama memecahkan berbagai permasalahan yang dihadapi penyuluhnya dalam menjalankan tusinya. Keberadaan Pokjaluh diharapkan dapat berkontribusi lebih intensif terhadap penanangan problematika para penyuluh di lapangan hingga akan dapat banyak membantu para penyuluh meyukseskan berbagai program yang diemban meningkatkan 


\section{DAFTAR PUSTAKA}

Adrian, Bob. (2019). Khazanah Sosial, Vol. 1 No. 1:31-48. "Pola Komunikasi Penyuluh Agama Islam Di Daerah 3T". Diambil kembali dari: http://journal.uinsgd.ac.id/index.php/ks Khazanah Sosial, Vol. 1 No. 1: 31-48 DOI: 10.15575/ks.v1i1.7144.

Amirulloh. (2016). Analisis Pengembangan Kompetensi Penyuluh Agama Pada Diten Bimas Islam Kementerian Agama Republik Indonesia Dalam Memelihara Kerukunan Umat Beragama. Jakarta: Young Progressive Muslims.

Clark, R.C. (2019). Evidence-based training methods: A guide for training professionals. American Society for Training and Development.

Elizar, dan Tanjung, Hasrudy. (2018). "Pengaruh Pelatihan, Kompetensi, Lingkungan Kerja terhadap Kinerja Pegawai". Maneggio: Jurnal IImiah Magister Manajemen, vol 1, No. 1, September 2018, 46-58 Diambil kembali dari, http://jurnal.umsu.ac.id/index.php/MANEGGIO ISSN 2623-2634 (online). DOI: https://doi.org/10.30596/maneggio.v1i1.2239

Goldstein, I.L., \& Ford, J. K. (2002). Training in Organization. Belmont: Wadsworth

Hadipoerwono. (1999). Tata Personalia. Bandung: Djembatan.

Kamil, Mustofa. (2010). Model Pendidikan dan Pelatihan, Konsep dan Aplikasi. Bandung: Alfabeta.

Kamus Besar Bahasa Indonesia versi daring. (2017). http://kbbi.web.id/kompetensi.

Madaus, G.F., M. Scriven, \& D. L. Stufflebeam (Eds.). (2001). Evaluation models. Boston: KluwerNijhoff.

Masadeh, Mouse. (2012). - Training, Education, Development and Learning: What is The Difference?||. European Scientific Journal, May, Vol. 8, No.10 pp.62-68.

Miles, M. B., \& Huberman, A. M. (1994). Qualitative data analysis: An expanded sourcebook. Thousand Oaks: Sage Publications.

Ramli, A.A., Anuar, F.L.M.K., Rosli, I., \& Jamalidan, S. A. (2018). The Relationship of Design, Implementation, Monitoring and Evaluation in Training and Development towards Employee Performance in Food and Beverage Industry. Global Business \& Management Research, 10(3)

Rusman. (2010). Model-model Pembelajaran (Mengembangkan Profesionalisme Guru) Edisi Kedua. Jakarta: RajaGrafindo Persada.

Sudjarwo. (2008). Evaluasi Kinerja Penyelenggaraan Pendidikan dan Pelatihan Kepemimpinan Tingkat IV pada Balai Pelatihan Keagamaan Semarang. Tesis yang Tidak Dipublikasikan. Program Pascasarjana Universitas Diponegoro Semarang. 
Sheeba, M. Jyothi dan Prabu B Christopher. (2020). "Exploring the Role of Training and Development In Creating Innovative Work Behaviors and Accomplishing Non-Routine Cognitive Jobs For Organizational Effectiveness".Journals of Critical Reviews Vol 7, Issue 4, 2020 Pp 263-267).

Spencer, Lyle, M.Jr. dan Signe M.Spencer. (1993). Competence at Work. New York: John Wiley\&Sons, Inc.

Kumpulan Keputusan dan Undang-Undang atau Peraturan Pemerintah:।

Kementerian Agama RI. (2005). Naskah Akademik Bagi Penyuluh Agama Puslitbang Kehidupan Keagamaan. Jakarta: Kemenag.

Kementerian Agama dan Kepala Badan Kepegawaian Negara. Keputusan bersama Menteri Agama RI dan Kepala Badan Kepegawaian Negara Nomor 574 tahun 1999 dan nomor 178 tahun 1999 tentang jabatan fungsional penyuluh agama dan angka kreditnya. (1999). JakartaL Kemenag. 